\title{
Kvinnan, mannen och den moderna utveck- lingen: Modernitet och genus i Elin Wägners och Ludvig Nordströms författarskap
}

\section{Av Peter Forsgren}

Denna artikel tar sin utgångspunkt i två olika, men sammanhängande forskningsprojekt, ett om Elin Wägner och ett om Ludvig Nordström. Intresset för problematiken kring modernitet och genus binder samman dessa projekt, liksom frågan hur olika berättandeformer, inte minst genrer, används i dessa författares prosa. Artikeln inleds med att beskriva några av de frågor som ställts inom forskningen kring mellan modernitet och genus och går vidare med att beskriva varför Elin Wägner och Ludvig Nordström är intressanta att undersöka ur detta perspektiv. Därefter följer en presentation av respektive forskningsprojekt medan senare delen av artikeln koncentrerar sig på ett par sena texter av respektive författare. Det rör sig om Elin Wägners romaner Vändkorset från 1935 och Vinden vände bladen, som blev hennes sista och som utkom 1947. I samband med den senare aktualiseras också debattboken Väckarklocka från 1941. De två texter av Ludvig Nordström jag särskilt tar upp är reportage- och debattboken Lort-Sverige från 1938, idag förmodligen författarens mest kända verk, och boken En dag av mitt liv som utkom 1942. Avslutningsvis kommer jag att jämföra samhällsvisionen och utopin i dessa sena verk av författarna.

Mycket har skrivit och forskats om det fenomen man kallar modernitet och det har analyserats utifrån en rad olika perspektiv och utgångspunkter. En någorlunda gemensam kärna går att urskilja bland dessa många analyser och definitioner. Modernitet kan förstås som ett slags paraplyterm för det tillstånd som präglar det moderna samhället och dess framväxt. Historiskt sett brukar man beskriva det som en process som är förknippad med den moderna vetenskapens och teknikens utveckling, med kapitalism, industrialisering, urbanisering och sekularisering, med demokratins framväxt, med masskommunikation osv. Som bland annat den svenske idéhistorikern Sven-Eric Liedman påpekat i sin bok I skuggan av framtiden. Modernitetens idéhistoria (1997) så rör det sig om en vittomfattande och mycket komplex moderniseringsprocess som också innehåller en rad motsägelsefulla drag. Det rör exempelvis den grundläggande motsättningen mellan rationalitet och subjektivitet, båda viktiga inslag i det moderna samhället, liksom den kluvna synen på vetenskap och teknik, som både kan uppfattas som samhällsförbättrande och som ett ballvarligt hot mot människan och hennes existens. 
Något som återkommande betonas i modernitetsforskningen är den oerhört stora förändringspotential själva moderniseringsprocessen innebär, det är ofta fråga om stora förändringar i förhållande till äldre, mer traditionella samhällsformer och värderingar. En av de internationellt mest inflytelserika forskare som särskilt studerat moderniteten inverkan på litteraturens område, Marshall Berman, har betonat denna förändringspotential redan i titeln till sin bok, Allt som är fast förflyktigas, utgiven på engelska 1982. Bermans modernitetstolkning har samtidigt mött en hel del kritik, inte minst från feministiska forskare som pekat på hur androcentrisk, d. v. s. manscentrerad Bermans modernitetsförståelse är. Han, liksom en rad andra manliga modernitetsforskare, tar mannen och produktionen som utgångspunkt då de beskriver och analyserar moderniteten. Den blir i deras perspektiv ett manligt utvecklingsprojekt som är kopplat till mannens aktivitet ute i samhället, främst genom arbete. Den innebär också frigörelse från traditionens band, från bindande bojor som inte sällan får representeras av kvinnan och hemmet. Berman visar bland annat detta i en analys av Goethes Faust, som också på ett närmast idealtypiskt sätt demonstrerar vilket pris det manliga moderniseringsprojektet har för andra, särskilt för kvinnan och naturen.

Den feministiska kritiken av den manligt dominerade tolkningen av moderniteten har för det första just riktat in sig på bilden av kvinnan, på de roller hon tilldelats. De har uppmärksammat hur hon ofta placerats vid sidan av den moderna utvecklingen, hur hon blivit förknippad med hem och tradition, med det förmoderna, hur hon beskrivits som den passiva mottagaren av de moderniseringens gåvor mannen bringar henne, i den mån hon inte har fått representera vissa av den moderna utvecklingens avigsidor, såsom överflödskonsumtion och nöjesindustri. För det andra har dessa feministiska forskare velat ändra synen på moderniteten genom i stället sätta kvinnan och reproduktionen i centrum. Ett exempel på detta är sociologen Barbara L. Marshall och hennes bok Engendering modernity. Feminism, social theory and social change (1994). Den feministiskt inriktade modernitetsforskningen har också uppmärksammat att kvinnliga författare vanligtvis gestaltar den moderna utvecklingen i delvis andra litterära former än sina manliga kollegor. Mindre sällan anknyter kvinnorna till modernistiska avantgarderiktningar, desto oftare använder de äldre, mer traditionstyngda genrer som familjeroman, melodram, idyll och bonderoman då de diskuterar och problematiserar kvinnans möjligheter och roller i det moderna samhället. Denna vad man kan kalla kvinnliga modernitetstradition inom romanens område är exempelvis mycket påfallande i Elin Wägners så kallade smålandsromaner och som skiljer dem från de romaner om moderna storstadskvinnor, såsom Norrtullsligan (1908) och Pennskaftet (1910), med vilka hon slog igenom.

En forskare som Nancy Armstrong har i boken Desire and Domestic Fiction. A Political History of the Novel (1987) påpekat att kvinnliga författare genom just familjeromansgenren tillhör pionjärerna då det gäller att skildra den moderna utvecklingen. Andra, som exempelvis Lisbeth Larsson i artikeln ”Modernismens kvinnliga avantgarde”, har menat att kvinnans förment marginaliserade position i den moderna utvecklingen gjort en rad kvinnliga författare till särskilt knivskarpa samhällsskildrare och civilisationskri- 
tiker och nämner bland exemplen Kerstin Ekman och hennes romanserie om kvinnorna och staden, den svit om fyra romaner som börjar med Häxringarna 1974. Kerstin Ekman och andra samtida kvinnliga författare ingår här i en mer eller mindre feministiskt influerad civilisationskritisk tradition som har en av sina främsta föregångare i Elin Wägner.

Elin Wägner och Ludvig Nordström föddes båda 1882 och ingår i en grupp författare som brukar kallas "tiotalisterna” i våra litteraturhistorier. Andra kända namn i denna grupp var Hjalmar Bergman, Sigfrid Siwertz, Gustaf Hellström och Sven Lidman. Wägner och Nordström hade varit verksamma en tid som journalister innan de debuterade som skönlitterära författare åren strax före 1910, och de utmärker sig bland gruppen tiotalister genom att vara särskilt upptagna av att beskriva och problematisera det moderna Sverige som växer fram under den första halvan av 1900-talet. I bådas samhällsskildringar finns såväl visionära som utopiska drag och båda drömmer de om en framtida värld präglad av fredlig samexistens. De uppfattar dock målet för samhällsutvecklingen liksom medlen för att komma dit mycket olika. Till en del är dessa skillnader genuskodade: medan Wägner hela tiden sätter kvinnan i centrum och problematiserar hennes position i förhållande till samhällsutvecklingen, är kvinnan länge i stort sett frånvarande i de romaner och reportage om det moderna Sveriges framväxt Nordström skriver. En annan viktig orsak är naturligtvis deras diametralt olika uppfattning om utvecklingens mål och medel: för Ludvig Nordström är sådant som industrialisering, rationalisering och urbanisering kungsvägen fram till det framtida lyckorike där världen genom dessa faktorer, liksom genom världsomspännande handel och kommunikationer, vuxit samman till en enda global stad - för Elin Wägner är samma fenomen just det som enligt hennes feministiskt och pacifistiskt präglade uppfattning driver utvecklingen och civilisationen åt fel håll och som ytterst hotar mänsklighetens existens på jorden.

I min bok I vansklighetens land. Genus, genre och modernitet i Elin Wägners smålandsromaner (2009) har jag undersökt sex romaner som utkom mellan åren 1918 och 1947. Sviten inleds med Åsa-Hanna och avslutas med Vinden vände bladen. Mellan dessa publicerades Den namnlösa 1922 och Silverforsen 1924 samt Svalorna flyga högt och Vändkorset 1929 respektive 1935. Gemensamt har de att de (förutom Silverforsen) utspelas i Småland, där av namnet smålandsromanerna, och att de spänner över ett brett register av väletablerade genrer såsom familje- och äktenskapsroman, bonderoman och idyll, kristen prövningsroman och melodram, legend och historisk krönika, historisk roman och kriminalroman, inte sällan i intrikata kombinationer. Ett utmärkande drag för samtliga smålandsromaner är att de har en fundamentalt dialogiska karaktär. Det är fråga om romaner som är dialogiska i den mening den ryske roman- och genreforskaren Michail Bachtin givit ordet, det vill säga romantexter där en rad olika perspektiv och röster bryts mot och flätas in i varandra samtidigt som det saknas ett överordnat centralperspektiv eller auktoritativ berättarröst som hierarkiserar dessa röster innebörden och ger deras yttranden en definitiv tolkning. I Elin Wägners smålandsromaner bringas härigenom en rad av den moderna utvecklingens olika perspektiv upp på så att säga textens yta för att brytas mot varandra inför läsarens öga. I exempelvis Åsa-Hanna ställs den kvinnliga 
huvudpersonen inför ett par radikalt olika livsalternativ och kampen mellan dem pågår enligt min tolkning fram till romanens slut utan att något riktigt avgörande sker mellan dem. I denna roman liksom i de övriga kan man också se hur språk och idéer med klart kristna och idealistiska drag ställs mot mer sekulariserade och moderna. På samma sätt som olika genrer vävs samman, flätas också diverse allegoriska tekniker med rötter i den bibliska textvärlden samman med en samhällskritisk, modern realistisk romanprosa. I vissa av romanerna, främst i Den namnlösa och Silverforsen, blir den kvinnliga huvudpersonen närmast ett slags utopisk gestalt som skall sammanbinda och överskrida de olika motsättningar romantexten spelar upp, i andra tenderar kvinnan att bli dessa motsättningars offer.

De två sista smålandsromanerna, Vändkorset och Vinden vände bladen, avviker från de föregående i så motto att de tydligare än dessa särskilt tydligt skildrar den moderniseringsprocess som det samtida svenska samhället genomgår. Vändkorset, som utspelar sig under några dygn vid en krisdrabbad småländsk möbelfabrik, formar sig till en folkhemsutopi med klara socialdemokratiska drag - den publicerades också först som följetong i den kooperativa tidskriften Konsumentbladet. Här återfinns flera av denna folkhemsutopis mest karaktäristiska drag, för vilket vändkorset, romanens centrala symbol är en bild: samarbete mellan arbete och kapital, klassamarbete och kompromiss, en modernisering av samhället som vilar på traditionens grund. Denna folkhemsutopi, med männen som huvudaktörer, är något relativt ovanligt i Elin Wägners författarskap. Mot denna ställs också två andra berättelser vilka problematiserar romanens huvudberättelse. Den viktigaste av dessa handlar om en kvinnlig läkare och hennes make, som är samhällets präst. De har sökt leva enligt idealet om kamratäktenskapet, en företeelse som var mycket uppmärksammad i det svenska 1930-talet, inte minst i den kvinnliga romanlitteraturen. Under romanens gång tvingas de emellertid inse att de misslyckats med att realisera detta ideal. Berättelsen om dem är en äktenskapsroman inom den större romanen och med klara drag av desillusionsberättelse. Denna binds dock samman med folkhemsutopin genom kvinnans förhoppningar att parets son skall kunna förena de världar och de värden hans föräldrar alltmer kommit att strida om.

Redan i sin inledning tydliggör Vinden vände bladen sin anknytning till samhällsdebatten i Väckarklocka, ett av de verk där Elin Wägners ekofeministiska civilisationskritik är som tydligast. Romanens inledande berättelse, som utspelar sig i övergången mellan hednisk och kristen tid, handlar om hur jättemön Ana möter krigaren Assar, blir besegrad av honom och därefter lämnar samhället för att uppgå i naturen. I denna berättelse gestaltas några av huvudtankarna från Väckarklocka: kvinnans förbundenhet med och respekt för naturen liksom hur mannen förskaffar sig makt genom våld, vilket leder till att han underkuvar såväl kvinnan som naturen. Berättelsen om Ana är en av romanens berättelser av kvinnlig förlust och marginalisering, men den liksom flera av de andra berättelserna innehåller samtidigt ett utopisk hopp om möjligheten till en förnyelse av detta matriakalt präglade "urtillstånd”. Så sker även i romanens senare delar, som utspelar sig från slutet av 1800-talet fram till krigsåret 1939. På romanens slutsidor lämnar 
åter en kvinna samhället för att bege sig ut i skogen där hon ämnar starta en nytt liv i samklang med naturen. Bakom sig lämnar hon en son som hon här förlorat till fadern och den moderna utvecklingen, detta till skillnad från sonens roll i Vändkorset. Sedd i detta ljus är utopin i den senare romanen mindre samkönad, också mindre optimistisk.

Då man som jag kommer till Ludvig Nordströms texter från att ha sysslat med Elin Wägners författarskap under ett antal år, är det ett par drag som genast faller i ögonen. Det ena är själva förhållningssättet till moderniteten. Nordström är i extremt hög grad en moderniseringsförespråkare och under en lång period ser han dessutom den moderna utvecklingen som en exklusivt manlig angelägenhet. Det andra är den monologiska karaktär hans texter har: Ludvig Nordström uppträder ömsom i rollen som ett slags romantisk bard som tolkar nationens historia och förklarar utvecklingens gång, ömsom i rollen som naturalistisk sociolog som med vetenskapliga anspråk ställer diagnos på samhället, uppletar dess sjuka och svaga punkter och som anger medlen för dess tillfrisknande. Det är en tämligen grandios författarhållning Ludvig Nordström vanligtvis intar och anspråket under framför allt 1920-talet gäller inget mindre än att i roman- och reportageform beskriva det moderna industri-Sveriges födelse, utveckling och uppgift i världen.

I ett av de reportage Ludvig Nordström publicerade under 1920-talet, Världs-Sverige (1928), och vars ämne är den internationellt framgångsrika svenska exportindustrin, ingår det en reseberättelse från Turkiet. Här beskrivs den modernisering landet genomgår under sin ledare Atatürk och ett grepp Nordström använder i denna berättelse är att polarisera den nya huvudstaden Ankara mot den gamla huvudstaden Konstantinopel. På ett för författaren karaktäristiskt sätt får Ankara bära den moderna utvecklingens olika kännetecken, medan Konstantinopel lika tydligt bär drag av denna utvecklings motsats. Beskrivningen av den senare staden innehåller en rad av de föreställningar om Orienten, det är nämligen det Konstantinopel kopplas samman med, som fått en av sina mest utförliga analyser i Edward Said bok Orientalism från 1978. Nordström använder då och då sådana eurocentriska beskrivningsmodeller i sina resereportage, bland annat i de två böcker som beskriver hans världsomsegling i början av 1930-talet och som heter Jag reste ut som svensk..., ...och blev helt enkelt människa, och som båda utkom 1932.

I sin bok Imperial leather (1995) analyserar Ann McClintock sambanden mellan genus, klass, ras och sexualitet $\mathrm{i}$ en kolonial kontext. McClintock visar att den bild av det moderna samhället och den moderna identitet som växte fram i Västeuropa under framför allt 1800-talet, särskilt då i Storbritannien som är fokus i hennes undersökning, har den vite europeiske medelklassmannen som norm. Det ur mitt perspektiv produktiva med McClintock är att hon i det sammanhanget visar hur denna moderna identitet samtidigt är formad i dialog med och i kontrast till andra grupper såsom kvinnor, arbetarklass, icke européer och då framför allt de koloniserade folken, att den moderne medelklassmannens identitet i själva verket är intimt förbunden med dessa andra grupper. Det är ett perspektiv som är högst relevant att lägga på Ludvig Nordströms olika texter från mellankrigstiden, såväl de skönlitterära som reportageböckerna, liksom på författarens diskussion av relationen mellan det moderna Sverige och globaliseringen. Särskilt fruktbart i detta sammanhang är McClintocks begrepp "panoptical time" är att 
använda i analysen av Nordströms texter. Med panoptisk tid, eller om man så vill panoptisk blick, menar McClintock följande: "the image of global history consumed - at a glance - in a single spectacle from a point of priviligied invisibility" (37). Det handlar om att se och bedöma samhälle och historia utifrån ett modernt utvecklingsperspektiv, något Ludvig Nordström är mycket upptagen av i samtliga texter jag studerar. För mig viktigt att undersöka är hur denna blick fungerar hos Nordström och vilka implikationer hans moderna samhällsvision har då det gäller genus, klass och etnicitet.

Vad än Ludvig Nordström skriver om under mellankrigstiden, så avläser han alltid hur långt den plats han undersöker befinner sig på har hunnit i den moderna utvecklingens skala, vilka positiva respektive negativa faktorer det finns, vad som bör göras osv. Detta gäller i hög grad hans mest kända reportagebok, Lort-Sverige (1938), där han enligt sin vanliga metod också upprättar en genomgående polaritet i texten mellan Nord och Syd: "ljuset”, det moderna, demokratiska Sverige ser han framför allt i de norrländska industrisamhällena, det kvardröjande, gamla Sverige med sin smuts, sin okunskap och sina gamla klassgränser möter han framför allt i de sydsvenska jordbruksbygderna. Hos Ludvig Nordströms bedöms alla platser, oberoende av var de ligger i världen, efter samma moderna - och universella - utvecklingsmodell.

Ludvig Nordströms modernitetsförståelse är länge mycket manscentrerad. Det är företagsledarna, läkarna, ingenjörerna och de välutbildade och medvetna arbetarna han främst skildrar och talar till. Kvinnorna är i hög grad frånvarande. Någon gång skriver författaren att han inte riktigt vet var de hör hemma i den moderna utvecklingen, någon gång får de representera det moderna samhällslivets avigsidor såsom lyxkonsumtion och ytlig nöjesindustri. Med Lort-Sverige ändras dock denna bild. På en rad ställen i denna bok diskuterar Nordström hemmen och kvinnorna. Han påpekar då att kvinnorna tyngs av ålderdomliga och ineffektiva arbetsformer i hemmen vilka behöver moderniseras. Vadan då denna omsvängning, detta plötsliga intresse? En hypotes jag har är att författaren blivit påverkad av 1930-talets folkhemsdebatt, som ju historikern Yvonne Hirdman, i sin bok Att lägga livet till rätt - studier i svensk folkhemspolitik, visat i hög grad utgick just från hemmen och kvinnorna.

I sin sista bok, En dag av mitt liv, som utkom samma år Ludvig Nordström dog, 1942, har intresset för kvinnorna och den moderna utvecklingen utvecklats ytterligare. Här påpekar författaren att moderniseringen av samhället visserligen inneburit stora lättnader för kvinnorna samtidigt som han understryker att kvinnorna fortfarande tyngs av en orättvis arbetsfördelning i hemmen på grund av männens ovilja att ta del av ansvaret för hemarbetet, en av alla dessa kvarlevande orättvisor Nordström vill undanröja genom sitt skrivande.

En dag av mitt liv, med underrubriken Lite vardagsdemokrati, skildrar en helt vanlig dag i författarens liv. Just vardagligheten och vanligheten ligger helt i linje med bokens innehåll och tematik. Det börjar med att författaren vaknar upp i sin säng och dels tänker på det världskrig som pågår och vars utgång vid den tidpunkt boken skrivs ännu är osäker, dels tänker på de olika människor och yrkesgrupper som håller samhället igång genom sitt arbete. En dag av mitt liv är en bok som uttrycker en stark tilltro till det 
folkhem som är under uppbyggnad i det samtida Sverige, en tilltro som framstår som desto starkare mot den mörka världskrigsbakgrunden. Det är också just det svenska folkhemmets demokratiska karaktär Ludvig Nordström lyfter fram och som Södermalm (där han själv bor) framför allt får konkretisera. I detta ideala samhälle existerar det inga klassgränser. Samhällslivet kännetecknas i stället av öppenhet och samarbete och här återfinns såväl de bildningstörstande arbetarna som de unga fäderna som tar hand om sina barn. Mot detta kontrasterar staden norr om Slussen där det gamla privilegie- och klassamhället fortfarande dominerar. Men även här finns demokratiska folkhemsöar: under dagen möter författaren dem bland annat på det moderna kontor han besöker liksom på den moderna restaurang där han äter lunch.

Hos Ludvig Nordström finns det aldrig något tvivel om vad som är utvecklingens mål, inte heller någon tvekan om att samhällets moderna utveckling är en strängt lagbunden och nödvändig process. Häri ligger förmodligen en av de starkaste drivkrafterna bakom författarens vilja att beskriva och förklara den moderna utvecklingen, troligtvis också förklaringen till att samhällsvision och utopi får förhållandevis konkreta former i hans texter.

Hur annorlunda förhåller det sig inte då med Elin Wägner. Till att börja med är själva utgångspunkten helt annorlunda. För henne leder inte den moderna utvecklingen åt rätt håll, tvärtom hotar framför allt den långt drivna mekaniseringen och rationaliseringen av samhället med en katastrof långt större än det pågående världskriget. En av de förmodligen mest provocerande tankar som Elin Wägner framför i Väckarklocka är ju att det inte råder någon avgörande skillnad mellan de stridande demokratiska staterna och deras motståndare, diktaturstaterna: båda samhällssystemen vilar ytterst på en rovdrift på natur och människor. För Elin Wägner blir det därför nödvändigt att formulera en samhällsvision som är radikalt annorlunda än det moderna industrisamhälle som hittills varit den dominerande modellen för utvecklingen. Hos henne blir därför den utopi som skisseras i debattboken just utopisk i ordets ursprungliga betydelse - en icke-plats - och därför mindre konkret än hos Ludvig Nordström. De två författarnas diametralt olika tolkningar av den moderna utvecklingen har, tycker jag så här avslutningsvis, relevans även för dagens samhällsdebatt: är mer av modern utveckling det enda medlet vi har för att uppnå demokrati och välstånd globalt eller är miljöförstöring, krig och förtryck en ofrånkomlig del av samma utveckling?

\section{REFERENSER}

Armstrong, Nancy (1987), Desire and domestic fiction. A political history of the novel, New York.

Bachtin, Michael (1991), Dostojevskijs poetik, Gråbo.

Berman, Marchall (2001), Allt som är fast förflyktigas. Modernism och modernitet, Lund. 
Hirdman, Yvonne (1989), Att lägga livet till rätta - studier i svensk folkhemspolitik, Stockholm.

Larsson, Lisbeth (1997), ”Modernismens kvinnliga avantgarde. Om utanförskapets betydelse för konst och konstnärer”, Tvärsnitt 1997:1, s. 26-35.

Liedman, Sven-Eric (1997), I skuggan av framtiden. Modernitetens idéhistoria, Stockholm.

Marshall, Barbara L. (1994), Engendering modernity. Feminism, social theory and social change, Oxford/Boston.

McClintock, Ann (1995), Imperial leather. Race, gender and sexuality in the colonial contest, London.

Said, Edward (1993), Orientalism, Stockholm. 